\title{
Interleukin (IL-6) Immunotherapy
}

\author{
Toshio Tanaka, ${ }^{1,2}$ Masashi Narazaki, ${ }^{2,3}$ and Tadamitsu Kishimoto ${ }^{4}$ \\ ${ }^{1}$ Department of Clinical Application of Biologics, Osaka University Graduate School of Medicine, \\ Osaka University, Osaka 565-0871, Japan \\ ${ }^{2}$ Department of Immunopathology, World Premier International Immunology Frontier Research Center, \\ Osaka University, Osaka 565-0871, Japan \\ ${ }^{3}$ Deparment of Respiratory Medicine, Allergy and Rheumatic Diseases, Osaka University Graduate School \\ of Medicine, Osaka University, Osaka 565-0871, Japan \\ ${ }^{4}$ Laboratory of Immune Regulation, World Premier International Immunology Frontier Research Center, \\ Osaka University, Osaka 565-0871, Japan \\ Correspondence: kishimoto@ifrec.osaka-u.ac.jp
}

Interleukin 6 (IL-6) is a prototypical cytokine for maintaining homeostasis. When homeostasis is disrupted by infections or tissue injuries, IL-6 is produced immediately and contributes to host defense against such emergent stress through activation of acute-phase and immune responses. However, dysregulated excessive and persistent synthesis of IL- 6 has a pathological effect on, respectively, acute systemic inflammatory response syndrome and chronic immune-mediated diseases. The IL-6 inhibitor, tocilizumab, a humanized anti-IL-6 receptor antibody, is currently being used for the treatment of rheumatoid arthritis, juvenile idiopathic arthritis, and Castleman disease. Lines of recent evidence strongly suggest IL-6 blockade can provide broader therapeutic strategy for various diseases included in acute systemic and chronic inflammatory diseases.

$T^{1}$ herapeutic strategy by either targeting immune-mediated molecules or their supplementation has been successful in various clinical applications and produced outstanding results. Interleukin 6 (IL-6) blockade therapy has also been successful for the treatment of several chronic immune-mediated diseases and is expected to be widely used for various diseases. The focus of this review is on current IL-6 blockade immunotherapy and future perspectives.

\section{BIOLOGICAL FUNCTIONS OF IL-6}

The human IL-6 gene was first cloned as B-cell stimulatory factor 2 (BSF-2), which induces B cells to produce immunoglobulin (Ig) (Kishimoto 1985; Hirano et al. 1986). Subsequently, IL-6 was shown to be a prototypical cytokine with a pleiotropic effect on inflammation, immune response, and hematopoiesis (Kishimoto 1989; Akira et al. 1993). When IL-6 acts on hepatocytes, it induces a broad range of acute phase proteins such as C-reactive protein (CRP), complement C3, serum amyloid A (SAA), fibrinogen, thrombopoietin, hepcidin, haptoglobin, and $\alpha 1$-antichymotrypsin, thus making IL-6 a vital mediator of acute phase response (Fig. 1) (Heinrich et al. 1990). However, if high-level concentrations of SAA in the serum persist for long periods, it can lead to a

Editors: Warren J. Leonard and Robert D. Schreiber

Additional Perspectives on Cytokines available at www.cshperspectives.org

Copyright (C) 2018 Cold Spring Harbor Laboratory Press; all rights reserved; doi: 10.1101/cshperspect.a028456

Cite this article as Cold Spring Harb Perspect Biol 2018;10:a028456 
T. Tanaka et al.

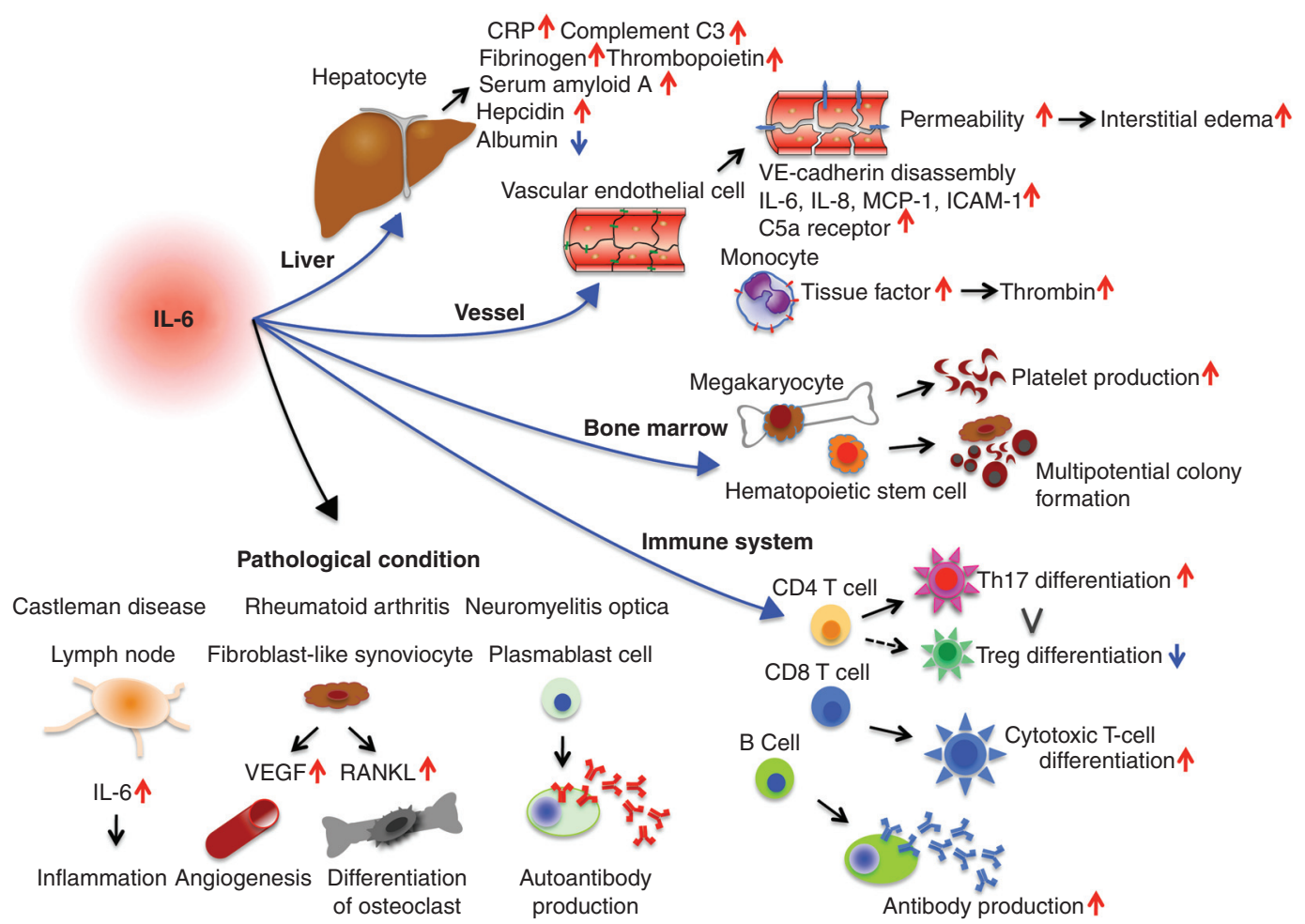

Figure 1. Pleiotropic effect of interleukin 6 (IL-6) (a cytokine featuring pleiotropic activity). It induces synthesis of acute phase proteins in liver such as C-reactive protein (CRP), complement C3, fibrinogen, thrombopoietin, serum amyloid A, and hepcidin, whereas it inhibits production of albumin. IL-6 also plays an important role in acquired immune responses by stimulating antibody production and inducing the differentiation of naïve CD4 ${ }^{+}$ $\mathrm{T}$ cells into effector T cells. IL-6 activates vascular endothelial cells to produce IL-6, IL-8, monocyte chemoattractant protein-1 (MCP-1), intercellular adhesion molecule (ICAM)-1, and C5a receptors, and induces vascular endothelial cadherin disassembly. In addition, IL-6 can promote differentiation or proliferation of several nonimmune cells. Because of its pleiotropic activity, dysregulated persistent or excessive production of IL-6 leads to the onset or development of various diseases. Excessive production of IL-6 is pathologically involved in the swollen lymph nodes of Castleman disease, whereas excessive IL-6 in synovial fluid stimulates fibroblast-like synoviocytes to produce vascular endothelial growth factor (VEGF) and receptor activator of nuclear factor of $\kappa \mathrm{B}(\mathrm{NF}-\kappa \mathrm{B})$ ligand (RANKL), which enhance angiogenesis and osteoporosis in patients with rheumatoid arthritis. IL-6 supports the survival of plasmablasts, which produce anti-aquaporin 4 antibodies in patients with neuromyelitis optica. Treg, Regulatory T cell.

serious complication: amyloid A amyloidosis (Gillmore et al. 2001). Moreover, IL-6-induced hepcidin production blocks the action of iron transporter ferroportin 1 on gut and thus reduces serum iron levels (Nemeth et al. 2004), resulting in hypoferremia and anemia associated with chronic inflammation. In hematopoiesis, IL-6 promotes hematopoietic stem cell differentiation as well as megakaryocyte maturation, which leads to the release of platelets (Ishibashi et al. 1989).
In addition to promoting differentiation of activated B cells into Ig-producing cells, in an acquired immune response, IL-6 regulates the direction of specific differentiation of naive $\mathrm{CD}^{+} \mathrm{T}$ cells. IL-6 in combination with transforming growth factor $\beta$ (TGF- $\beta$ ) is indispensable for T helper (Th)17 differentiation, whereas IL- 6 inhibits TGF- $\beta$-induced regulatory T-cell (Treg) differentiation (Kimura and Kishimoto 2010). This effect causes up-regulation of the Th17/Treg balance, which is patho- 
logically involved in the development of various autoimmune and chronic inflammatory diseases. It has also been shown that IL- 6 can promote $\mathrm{T}$ follicular helper cell differentiation as well as production of IL-21 (Ma et al. 2012), which also regulates Ig synthesis.

Furthermore, IL-6 induces a variety of biological activities. When IL- 6 is produced in bone marrow stromal cells, it stimulates fibroblast-like synoviocytes to produce the receptor activator of the nuclear factor $\kappa \mathrm{B}(\mathrm{NF}-\kappa \mathrm{B})$ ligand (RANKL) (Hashizume et al. 2008), which is essential for the differentiation and activation of osteoclasts (Kotake et al. 1996). IL-6 can also induce excess production of vascular endothelial growth factor (VEGF), which leads to both enhanced angiogenesis and increased vascular permeability (Cohen et al. 1996).

Not only does IL-6 promote production of fibrinogen and platelet release but it also activates the coagulation system. IL- 6 induces tissue factor (TF) on the cell surface of monocytes (Fig. 1) (Neumann et al. 1997), which promotes coagulation by initiating the extrinsic coagulation pathway, and in turn leads to thrombin production. These activities of IL-6 lead to a hypercoagulable state and thrombosis. IL-6 has also been shown to activate vascular endothelial (VE) cells. VE-cadherin is an important molecule, which promotes endothelial adhesion of adjacent cells by means of homophilic binding, while its disassembly by IL-6 leads to vascular leakage (Kruttgen and Rose-John 2011). Moreover, IL-6 increases production of VEGF, which induces the phosphorylation and internalization of VE-cadherin, and thus has a potent vascular permeability effect on endothelial cells (Esser et al. 1998; Desai et al. 2002). Vascular permeability by IL-6 itself or via induction of VEGF then leads to interstitial ede$\mathrm{ma}$ and elevates tissue pressure resulting in tissue damage. The complex IL-6/sIL-6R (soluble interleukin 6 receptor) can activate $\mathrm{VE}$ cells to produce IL-6, IL-8, and MCP-1 as well as augment intercellular adhesion molecule (ICAM)-1 expression, which results in leukocyte recruitment (Romano et al. 1997). IL-6 up-regulates the complement $5 \mathrm{a}$ receptor $(\mathrm{C} 5 \mathrm{aR})$ on endothelial cells, thus increasing their responsiveness to $\mathrm{C} 5 \mathrm{a}$, which functions as an anaphylatoxin, causes smooth muscle contraction and histamine release from mast cells, and results in further enhancement of vascular permeability (Laudes et al. 2002; Riedemann et al. 2003). Furthermore, IL-6 has been shown to weaken papillary muscle contraction, leading to myocardial dysfunction (Finkel et al. 1992; Pathan et al. 2004). These multiple effects of IL-6 in coagulation cascade, vascular permeability, and myocardial dysfunction thus play a pathological role in tissue hypoxia, hypotension, disseminated intravascular coagulation (DIC), and multiple organ dysfunction, all characteristic features of systemic inflammatory response syndrome (SIRS).

\section{IL-6-MEDIATED SIGNALING PATHWAY}

The function of IL- 6 is initiated by its binding to an IL-6 receptor (IL-6R), and exists in two forms, $80-\mathrm{kDa}$ transmembrane and $50-55-$ kDa sIL-6R (Fig. 2) (Yamasaki et al. 1988; Narazaki et al. 1993). Transmembrane IL-6R is expressed in limited cells such as leukocytes and hepatocytes, whereas sIL-6R is in human serum. Once IL-6 binds to transmembrane or sIL-6R, the complex in turn induces homodimerization of gp130 triggering a downstream signal cascade (Fig. 2) (Hibi et al. 1990; Kishimoto et al. 1992; Murakami et al. 1993). The functional receptor is a hexamer with two molecules of IL-6 and two of IL-6R as well as two molecules of gp130 (Boulanger et al. 2003). Tocilizumab, the IL-6 inhibitor developed first, is a humanized anti-IL-6R monoclonal antibody, which binds to transmembrane and sIL-6R and inhibits IL-6 binding to both receptors. The pleiotropic effect of IL- 6 can be explained by the broad expression of gp130 on various cells (Taga and Kishimoto 1997). Homodimerization of gp 130 allows the Janus kinases (JAKs) such as JAK1, JAK2, and tyrosine kinase 2 (TYK2) to come close to each other and to lead to phosphorylation in the cytoplasmic tyrosine residues of gp130. The Src homology 2 (SH2)-domaincontaining molecules, signal transducers and activators of transcription (STAT)3, STAT1, and $\mathrm{SH} 2$-domain-containing protein-tyrosine 
T. Tanaka et al.

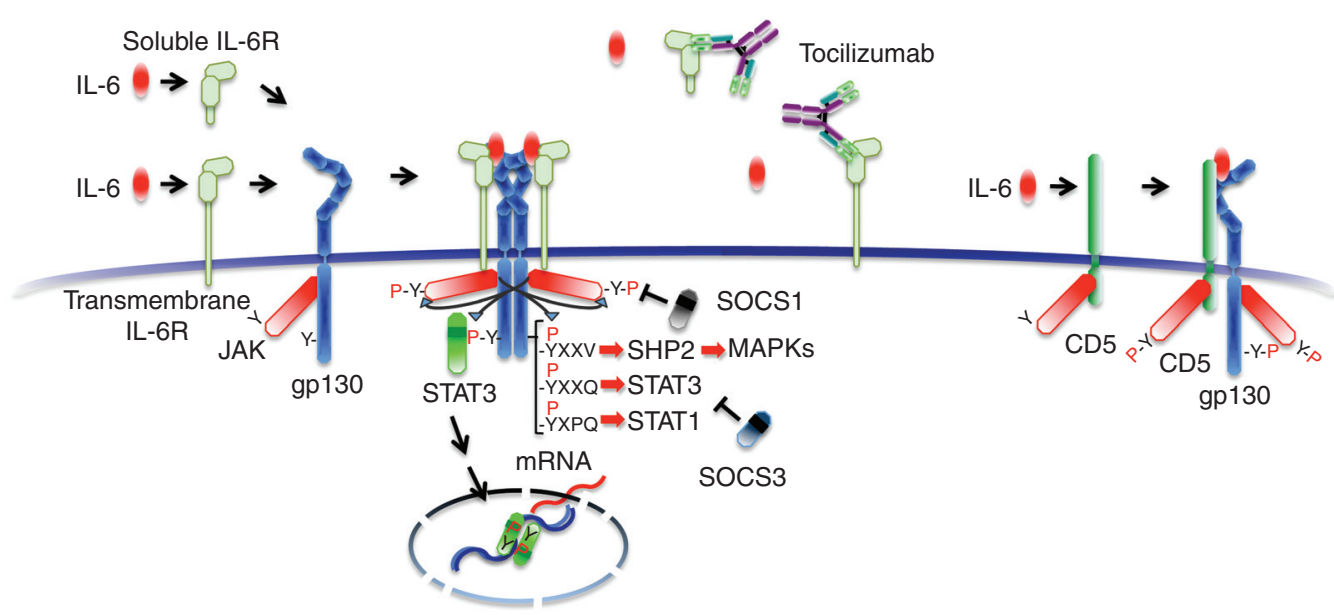

Figure 2. Interleukin 6 (IL-6) receptor-mediated signaling pathway and an IL-6 inhibitor, the humanized antiIL-6 receptor antibody tocilizumab. IL-6 binds to soluble and transmembrane IL-6R and the resultant complex induces homodimerization of gp130, leading to activation of Janus kinase (JAK)1, JAK2, and tyrosine kinase 2 (TYK2). JAKs, in turn, phosphorylate cytoplasmic tyrosine-based motifs of gp130, followed by attracting Src homology 2 (SH2)-containing molecules $\mathrm{SH} 2$ domain-containing protein-tyrosine phosphatase 2 (SHP2) to YXXV, signal transducers and activators of transcription (STAT)3 to YXXQ, or STAT1 to YXPQ (Y, tyrosine; V, valine; Q, glutamine; $\mathrm{P}$, proline; $\mathrm{X}$, any amino acid), which results in a downstream signal. Of the negative feedback molecules in cytoplasm, negative feedback molecules, suppressor of cytokine signaling (SOCS) 1 binds to and inhibits JAK, whereas SOCS3 binds to gp130 and inhibits STAT3 activation. A humanized anti-IL-6 receptor (IL-6R) antibody, tocilizumab, blocks the IL-6-mediated signaling pathway by inhibiting IL-6 binding to both the soluble and transmembrane form of IL-6Rs. IL-6 can also bind to CD5 with low affinity, which leads to STAT3 activation. MAPKs, Mitogen-activated protein kinases.

phosphatase 2 (SHP2) are attracted to the tyrosine-phosphorylated motifs of gp130, YXXV for SHP2, YXXQ for STAT3, and YXPQ for STAT1 (Y, tyrosine; V, valine; $\mathrm{Q}$, glutamine; $\mathrm{P}$, proline; $\mathrm{X}$, any amino acid). STAT3 and STAT1 are then phosphorylated by the JAKs and translocate to the nucleus, which generates the transcriptional output (Fig. 2). SHP2 activates the mitogen-activated protein (MAP) kinase pathway (Kishimoto et al. 1994). This is followed by the induction of the various IL-6-responsive genes, which include acute phase proteins, by STAT3 activation. STAT3 also induces the suppressor of cytokine signaling (SOCS) 1 and SOCS3, which bind to tyrosine-phosphorylated JAK (Naka et al. 1997) and tyrosine-phosphorylated gp130 (Schmitz et al. 2000), respectively, to stop IL-6 signaling by means of a negative feedback loop.

It was found recently that IL- 6 can bind to another surface molecule, CD5, and also acti- vate STAT3 via gp130 and JAK2 (Zhang et al. 2016). STAT3 activation up-regulates CD5 expression, forming a feedforward loop that may play a critical role in the promotion of cancer development by $\mathrm{CD}^{+} \mathrm{B}$ cells. However, the binding affinity between IL-6 and sIL-6R is around $1 \mathrm{nM}$, whereas IL- 6 binds to CD5 at $100 \mathrm{~nm}$. This means that interaction of IL-6 with CD5 is doubtful under physiological conditions, but can occur under pathological conditions when the IL-6 level is highly elevated (Masuda and Kishimoto 2016).

\section{REGULATORY MECHANISM OF IL-6 SYNTHESIS}

When emergent stress such as infections or tissue injuries occur, IL-6 is produced immediately by innate immune cells such as macrophages and monocytes and plays a major role in removal of infectious agents and in tissue repair by 
activating immune and acute-phase responses. When such stress has been eliminated from the host and homeostasis is fully recovered, IL-6 synthesis is terminated. IL-6 production is therefore tightly regulated in response to environmental stress and its regulation is controlled through transcriptional and posttranscriptional mechanisms (Tanaka and Kishimoto 2014; Tanaka et al. 2014a). However, if such regulation is disrupted, excessive or persistent production of IL-6 is induced and causes the development of various diseases. Not only immune-mediated cells but also mesenchymal cells, VE cells, fibroblasts, and many other cells have been found to produce IL-6 under physiological and pathological conditions (Akira et al. 1993).

It has been shown that a number of transcription factors regulate IL-6 gene transcription. The functional cis-regulatory elements in the $5^{\prime}$ flanking region of the human IL- 6 gene have been identified as binding sites for NF- $\kappa \mathrm{B}$, specificity protein 1 , nuclear factor IL-6 ([NFIL-6], also known as C/EBP- $\beta$ ), activator protein 1 , and interferon regulatory factor 1 (Libermann and Baltimore 1990; Akira and Kishimoto 1992). Interestingly, certain viral products can enhance the DNA-binding activity of NF- $\mathrm{BB}$ and NF-IL-6, which results in increased IL-6 messenger RNA (mRNA) transcription. For example, interaction with NF- $\mathrm{KB}$ of the transactivator protein (TAX), derived from the human $T$ lymphotropic virus 1 enhances IL-6 production (Ballard et al. 1988), whereas the DNA-binding activity of both NF- $\kappa B$ and NF-IL- 6 is enhanced by the transactivator of the transcription protein (TAT), of human immunodeficiency virus 1 (HIV1) (Scala et al. 1994). Moreover, some microRNAs (miRNAs) directly or indirectly regulate transcription activity. For example, interaction of miRNA-155 with the $3^{\prime}$-untranslated region (UTR) of NF-IL-6 suppressing NF-IL-6 expression (He et al. 2009).

IL-6 expression is also controlled by posttranscriptional regulation (Chen and Shyu 1995; Anderson 2008). Initiation of mRNA translation is controlled by the $5^{\prime}$ UTR, and the stability of mRNA by the $3^{\prime}$ UTR, which in turn is regulated by modulation of AU-rich ele- ments (AREs) located in the $3^{\prime}$-UTR region. A number of RNA-binding proteins and miRNAs bind to the $3^{\prime}$ UTRs and regulate the stability of IL-6 mRNA. The nuclease regulatory RNase-1 (Regnase-1) plays a role in destabilizing IL-6 mRNA, and it was found that the relevant knockout mice spontaneously developed autoimmune diseases accompanied by splenomegaly and lymphadenopathy (Matsushita et al. 2009). Another RNA-binding protein, Roquin, recognizes target mRNAs overlapping with Regnase-1 (Mino et al. 2015). However, their localizations and states of the target mRNAs are spatiotemporally different. Regnase-1 degrades transcriptionally active mRNA in cytoplasm, endoplasmic reticulum, and ribosome, whereas Roquin degrades transcriptionally inactive mRNA in stress granules and processing bodies. On the other hand, we identified a unique RNAbinding protein, AT-rich interactive domaincontaining protein $5 \mathrm{a}$ (Arid5a), which binds to the $3^{\prime}$ UTR of IL-6 mRNA, resulting in selective stabilization of IL- 6 but not of tumor necrosis factor $\alpha$ (TNF- $\alpha$ ) or IL-12 mRNA (Masuda et al. 2013). Arid5a expression is enhanced in macrophages in response to lipopolysaccharide (LPS), IL- $1 \beta$, and IL-6, and also induced under Th17polarizing conditions in T cells. Arid5a gene deficiency inhibits elevation of IL-6 levels in LPS-injected mice and development in experimental autoimmune encephalomyelitis. Arid5a counteracts the degrading effect of Regnase- 1 on IL-6 mRNA (Fig. 3), indicating that there is a balance between Arid5a and Regnase-1, playing an important role in IL-6 mRNA stability. Moreover, we also found that Arid5a is an important regulator for differentiation of naïve $\mathrm{CD} 4^{+} \mathrm{T}$ cells into Th17 cells through selective stabilization of STAT3 mRNA (Masuda et al. 2016). A similar observation was made in IL-6 mRNA metabolism, in which Arid5a can counteract Regnase-1-mediated STAT3 degradation. These findings strongly suggest that the formation of a positive loop, consisting of IL-6, STAT3, and Arid5a, plays an important role in the exaggerated expression of IL-6 and accelerated IL-6R-mediated signaling, indicating that it conceivably plays a pathological role in various IL-6-mediated diseases. 
T. Tanaka et al.

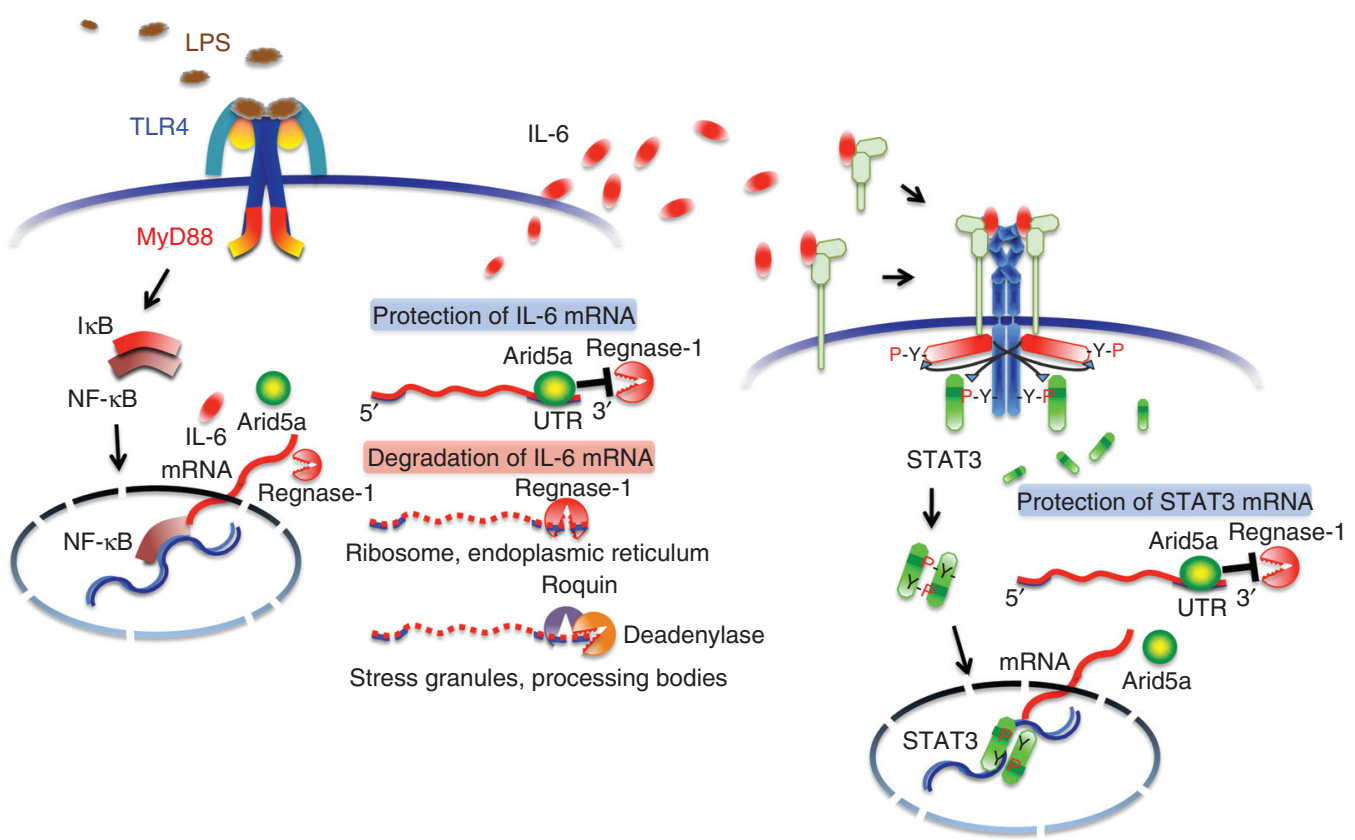

Figure 3. Arid5a stabilizes interleukin 6 (IL-6) and Stat3 messenger RNAs (mRNAs). Toll-like receptor (TLR)4 recognizes lipopolysaccharide (LPS) and induces IL-6 mRNA via activation of the signaling pathway of nuclear factor of $\kappa \mathrm{B}(\mathrm{NF}-\kappa \mathrm{B})$. Regnase-1 promotes IL-6 mRNA degradation in ribosomes and the endoplasmic reticulum, whereas Arid5a inhibits the destabilizing effect of Regnase-1. Roquin, which requires deadenylase for its function, degrades inactive mRNA in stress granules and processing bodies. In naïve CD $4^{+} \mathrm{T}$ cells, IL- 6 activates signal transducers and activators of transcription (STAT) 3 and induces transcription of IL-6-target genes, including Arid5a, which protects STAT3 mRNA from the degrading effect of Regnase- 1 . The regulation of IL-6 and STAT3 mRNAs by Arid5a is important for the IL-6 production and strength of the IL-6R-mediated signaling.

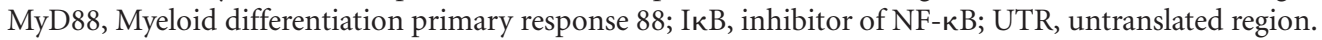

\section{IL-6 BLOCKADE IMMUNOTHERAPY}

The association of IL- 6 overexpression and disease development was first found in a patient with cardiac myxoma, who presented with fever, polyarthritis with positivity for antinuclear antibody, elevated CRP level, and hypergammaglobulinemia. The myxoma tissue was highly stained with anti-IL-6 antibody, which suggested that continuous production of IL-6 from myxoma tissue might have contributed to chronic inflammation and autoimmunity ( $\mathrm{Hi}-$ rano et al. 1987). Follow-up studies have shown that dysregulation of IL-6 production occurs in the synovial cells of rheumatoid arthritis (RA) (Hirano et al. 1988), myeloma cells (Kawano et al. 1988), germinal center B cells in swollen lymph nodes of Castleman disease (Yoshizaki et al. 1989), and peripheral blood cells or tissues involved in various other autoimmune and chronic inflammatory diseases and even malignant cells in cancers (Akira et al. 1993). Serum concentrations of IL- 6 are $<4 \mathrm{pg} / \mathrm{mL}$ under healthy conditions, but IL-6 levels can increase in various ways, depending on the disease and its severity, usually up to several tens or even hundreds of $\mathrm{pg} / \mathrm{mL}$ in chronic diseases, whereas in a cytokine storm the level can increase dramatically to $>1000 \mathrm{pg} / \mathrm{mL}$ and, in severe cases, reach a level measured in $\mu \mathrm{g} / \mathrm{mL}$.

In addition, the pathological role of IL-6 in disease development has been confirmed in a number of animal disease models, in which it has been shown that IL- 6 blockade by means of gene knockout or administration of neutralizing anti-IL-6 or anti-IL-6R antibody is preven- 
Interleukin 6 Immunotherapy

tive or leads to therapeutic suppression of disease development (Kishimoto 2005; Tanaka et al. 2012). These findings led to the notion that IL-6 targeting might constitute a novel treatment strategy for various diseases, leading to the development of tocilizumab, a humanized anti-IL-6R monoclonal antibody of the IgG1 class (Sato et al. 1993) that blocks IL-6mediated signal transduction by inhibiting IL-6 binding to transmembrane and sIL-6R (Fig. 2).

\section{DISEASES FOR WHICH TREATMENT WITH TOCILIZUMAB HAS BEEN APPROVED}

Currently, tocilizumab is approved for the treatment of Castleman disease, RA, and juvenile idiopathic arthritis (JIA).

\section{Castleman Disease}

Following the first in-human clinical study in which tocilizumab was administered to a patient with multiple myeloma, the clinical trial of tocilizumab was performed with seven patients with Castleman disease, a chronic lymphoproliferative disorder, in which IL-6 is pathologically produced in germinal center B cells in the involved lymph node(s). These patients presented with severe inflammatory symptoms and laboratory findings such as high fever, anemia, increased levels of acute-phase proteins, hypoalbuminemia, and hypergammaglobulinemia. Administration of tocilizumab promptly ameliorated clinical symptoms, normalized serum CRP levels, and improved anemia, serum albumin concentration, and hypergammaglobulinemia (Nishimoto et al. 2000). The outstanding efficacy of tocilizumab was confirmed in another clinical trial with an enrollment of 28 patients with Castleman disease (Nishimoto et al. 2005), and these results led to the approval of tocilizumab in Japan in 2005. Moreover, a chimeric monoclonal antibody to IL-6, siltuximab, was approved by the U.S. Food and Drug Administration (FDA) in 2014 for the treatment of patients with multicentric Castleman disease who are human immunodeficiency virus negative and human herpesvirus- 8 negative (Deisseroth et al. 2015).

\section{Rheumatoid Arthritis}

The first randomized controlled trial of tocilizumab for RA was performed with 45 patients who received a single intravenous dose of either $0.1,1,5$, or $10 \mathrm{mg} / \mathrm{kg}$ of tocilizumab or placebo (Choy et al. 2002). At week 2, a significant difference was observed between the group treated with $5 \mathrm{mg} / \mathrm{kg}$ of tocilizumab and the placebo group. Five patients (56\%) in the tocilizumab cohort and none in the placebo cohort attained 20\% improvement based on the American College of Rheumatology Criteria (ACR20), or 20\% improvement in tender or swollen joints as well as $20 \%$ improvement of three of the other five criteria. At 12 weeks, a multicenter, doubleblind, and placebo-controlled phase II trial was then performed in Japan (Nishimoto et al. 2004). In this trial, 164 patients with RA were randomized for intravenous administration of either 8 or $4 \mathrm{mg} / \mathrm{kg}$ of tocilizumab or placebo every 4 weeks. By week 12, an ACR20\% response had been attained for $78 \%, 57 \%$, and $11 \%$ of the patients injected with $8 \mathrm{mg} / \mathrm{kg}, 4 \mathrm{mg} / \mathrm{kg}$ of tocilizumab, and placebo, respectively. Seven subsequent independent phase III clinical trials performed worldwide as well as in Japan also verified the outstanding efficacy of tocilizumab for the suppression of disease activity and joint destruction progression with satisfactory safety, so that this biologic is currently approved for RA treatment in more than 130 countries (Tanaka et al. 2013, 2014b). Guidelines published by the European League Against Rheumatism (EULAR) and ACR recommends tocilizumab as one of eight first-line biologics to be used for RA patients with an inadequate response to the standard disease-modifying antirheumatic drug (DMARD) methotrexate (MTX) (Smolen et al. 2014; Singh et al. 2016). Firstline biologics include five TNF inhibitors, a Tcell activation blocker (CTLA4-Ig), and a B-cell depletory agent (rituximab), as well as tocilizumab. However, tocilizumab is the only biologic that has proved to be more efficacious as monotherapy than MTX or other DMARDs (Tanaka et al. 2013). TNF inhibitors require the concomitant use of MTX to achieve their maximal effects, whereas tocilizumab monotherapy is as 
T. Tanaka et al.

effective as the combination therapy of tocilizumab plus MTX for the suppression of disease activity. Moreover, a direct head-to-head comparison of tocilizumab and adalimumab, a fully human anti-TNF $\alpha$ antibody, showed that tocilizumab as monotherapy was superior to adalimumab, as assessed with several indices of disease activity (Gabay et al. 2013). Thus, the most powerful antirheumatic biological currently available is tocilizumab.

\section{Juvenile Idiopathic Arthritis}

The third disease for which tocilizumab is onlabel is systemic JIA (sJIA), which is a subtype of chronic childhood arthritis leading to joint destruction and functional disability and is accompanied by systemic inflammation. A clinical trial, consisting of a 6-week open-label leadin phase and a 12-week double-blind phase, was performed with an enrollment of 56 children with sJIA (Yokota et al. 2008). By week 6 , tocilizumab treatment $(8 \mathrm{mg} / \mathrm{kg}$, every 2 weeks, intravenously) had resulted in ACR Pediatric $30 \%, 50 \%$, and $70 \%$ responses for $91 \%$, $86 \%$, and $68 \%$ of the patients, respectively. Forty-three patients continued to the double-blind phase and 16 of the 20 patients $(80 \%)$ in the tocilizumab group could maintain an ACR Pediatric $30 \%$ response, while only four of the 23 patients (17\%) in the placebo group could maintain the same response. Moreover, a global phase III trial, with an enrollment of 112 children with active sJIA, has also shown that tocilizumab is highly efficacious for the suppression of disease activity of sJIA (De Benedetti et al. 2012).

\section{BROAD APPLICATION OF IL-6 BLOCKADE IMMUNOTHERAPY FOR VARIOUS CHRONIC IMMUNE-MEDIATED DISEASES}

In addition, a variety of case studies, series, and pilot studies of off-label use with tocilizumab have produced favorable results, suggesting tocilizumab may become established as a novel drug for the treatment of various chronic intractable immune-mediated diseases (Fig. 4) (Tanaka et al. 2012, 2014b). These include au- toimmune diseases, chronic inflammatory diseases, and other diseases such as atherosclerosis, diabetes mellitus, orthopedic diseases, cancers, and psychological diseases, and various clinical trials of tocilizumab are in progress. Specifically, there are strong indications based on accumulated evidence that tocilizumab appears to be highly promising for the treatment of systemic sclerosis (SSc), neuromyelitis optica (NMO), large-vessel vasculitis, and polymyalgia rheumatica (PMR).

\section{Systemic Sclerosis}

SSc is a connective tissue disease, characterized by skin and tissue fibrosis, vasculopathy, and immune abnormalities. Various studies analyzed the pathogenic mechanisms of SSc, but no effective treatment has been established. However, because IL-6 plays a role in formation of these characteristics and IL-6 elevation was found in serum as well as involved tissues of patients, IL-6 may well be a potential target molecule for SSc.

We were the first to report the beneficial effect of tocilizumab for two patients with SSc (Shima et al. 2010), and the results of the subsequent phase II/III, multicenter, randomized, double-blind, and placebo-controlled study (NCT01532869) have recently been reported (Khanna et al. 2016). In this trial, 87 patients were enrolled: 43 were assigned to receive weekly $162 \mathrm{mg}$ of subcutaneous tocilizumab and 44 to receive placebo. The primary end point was a significant difference in the mean change from baseline in the modified Rodnan skin score (MRSS), an index of evaluating skin thickness. The least squares mean change in the score at 24 weeks was -3.92 for the tocilizumab group and -1.22 for the placebo group (difference -2.70 , $95 \%$ CI: -5.85 to $0.45 ; p=0.09$ ), so that the primary end point was not attained. However, fewer patients administered with tocilizumab than placebo showed a decline in the percentage of predicted forced vital capacity at 48 weeks ( $p$ $=0.0373$ ), indicating that worsening in respiratory disturbance is significantly suppressed by tocilizumab. These results led to the granting by the FDA to tocilizumab of a Breakthrough 


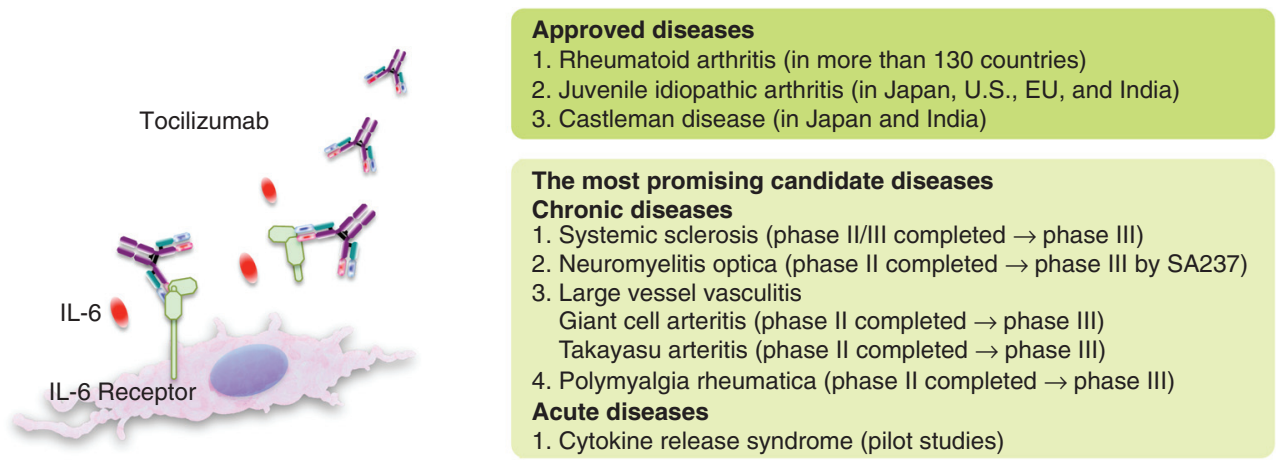

Candidate diseases

Autoimmune diseases

- Polymyositis/dermatomyositis

- Systemic lupus erythematosus

- Relapsing polychondritis

- Autoimmune hemolytic anemia

- Acquired hemophilia A

- Graves' orbitopathy

- Sjogren's syndrome

Inflammatory diseases

- Adult-onset Still's disease

- Amyloid A amyloidosis

- $\mathrm{RS}_{3} \mathrm{PE}$

- Behcet's disease

- Noninfectious uveitis, uveitic

macular edema
- Crohn's disease

- Graft-versus-host disease

- Autoinflammatory syndrome

- Pulmonary arterial hypertension

- IgG4-related disease

Acute diseases

- Systemic inflammatory response syndrome,

including severe sepsis, septic shock,

tissue injury (burn, crush syndrome, heat stroke),

acute pancreatitis

- Hemophagocytic lymphohistiocytosis

- Macrophage activation syndrome

- Myocardial Infarction
Other diseases

- Atherosclerosis

- Diabetes mellitus (type I and II)

- Sciatica

- Osteoarthritis

- Fibrous dysplasia of bone

- Amyotrophic lateral sclerosis

- Schizophrenia, depression

- Multiple myeloma

- B-CLL AML

- Pancreatic cancer

- Cancer-related cachexia

- HIV infection

Figure 4. Interleukin 6 (IL-6) blockade immunotherapy for various diseases. Currently, tocilizumab is approved for the treatment of rheumatoid arthritis, systemic and polyarticular juvenile idiopathic arthritis, and Castleman diseases. It is expected that IL-6 blockade immunotherapy will constitute a novel therapeutic strategy for a wide range of diseases. In particular, the most promising candidate diseases are systemic sclerosis, neuromyelitis, large vessel vasculitis, polymyalgia rheumatica, and cytokine release syndrome (CRS), and ongoing clinical trials are in progress. RS3PE, Remitting seronegative symmetrical synovitis with pitting edema; B-CLL, B-cell chronic lymphocytic leukemia; AML, acute myelogenous leukemia; HIV, human immunodeficiency virus.

Therapy Designation for SSc and a subsequent clinical trial (NCT02453256) was started recently. In this phase II/III study, analyses of gene expression using microarray technology for skin biopsy specimens showed that, by 24 weeks, 16 genes had been definitely down-regulated by tocilizumab and 12 of these genes belonged to the M2 macrophage cluster. M2 macrophages are known to play a pathological role in fibrosis through the release of inflammatory and fibrotic factors. In addition, a recent study reported that IL- 6 primes macrophages for IL-4-dependent M2 polarization by inducing IL-4 receptor expression (Mauer et al. 2014), so that the effect of tocilizumab on SSc may be mediated by modulating M2 macrophage activity. This trial did not evaluate the efficacy of tocilizumab for pulmonary arterial hypertension $(\mathrm{PAH})$, which is a severe, refractory disease caused by an increase of blood pressure in the pulmonary artery, often complicated with SSc. In a hypoxia-induced PAH model, however, IL6 blockade resulted in a striking amelioration in PAH and prevented IL-21-mediated polarization of primary alveolar macrophages to M2 macrophages (Hashimoto-Kataoka et al. 2015). Because this finding suggests that IL-6 blockade could also become a novel therapeutic strategy for PAH, a phase II clinical trial (NCT02676947) has been initiated. 
T. Tanaka et al.

\section{Neuromyelitis Optica}

$\mathrm{NMO}$ is a chronic inflammatory demyelinating disease of the central nervous system primarily affecting the spinal cord and optic nerves. Autoantibodies against aquaporin-4 (AQP-4), an astrocyte water channel protein, play a major part in the disease development. Anti-AQP-4 antibodies are produced by the plasmablast population showing a $\mathrm{CD} 19^{\text {intermediate }} \mathrm{CD} 29^{\text {high }} \mathrm{CD} 38^{\text {high }} \mathrm{CD} 180^{\text {negative }}$ phenotype, which is increased in the peripheral blood of NMO patients (Chihara et al. 2011). An in vitro study showed that IL-6 enhanced the survival of the plasmablast population, but the addition of tocilizumab into the culture diminished its survival and inhibited the production of anti-AQP-4 antibody, thus suggesting that tocilizumab is promising for the treatment of NMO. Indeed, prominent beneficial effects of tocilizumab in the suppression of relapse rate and neuropathic pain have been reported for refractory patients with NMO (Araki et al. 2014). This has led to clinical trials (NCT02028884 and NCT02073279, now in progress) for treatment of NMO with a new humanized antibody against IL-6R (SA237) with a longer half-life, which was generated from tocilizumab using an antibody structural optimization technique (Igawa et al. 2010).

\section{Giant Cell Arteritis and Polymyalgia Rheumatica}

Giant cell arteritis (GCA) is a chronic inflammatory disease of large and medium-sized arteries that affects persons over 50 years of age. Although its etiology remains unknown, IL-6 has a central role in the pathogenesis of GCA. The serum concentrations of IL- 6 are elevated at the onset and during clinical relapse, while it has been reported that tissue-infiltrating cells produce major quantities of IL-6 as well as Th1-type cytokine interferon $\gamma($ IFN- $\gamma)$ in patients with GCA. Subsequent to various reports regarding off-label use of tocilizumab for intractable GCA patients, a phase II, randomized, double-blind placebo-controlled trial (NCT01450137) was performed in Switzerland (Villiger et al. 2016).
Thirty patients with new-onset or relapsing GCA were assigned (2:1) to receive tocilizumab $(8 \mathrm{mg} / \mathrm{kg}$, every 4 weeks) or placebo intravenously until week 52 . Both groups received oral prednisolone, starting at $1 \mathrm{mg} / \mathrm{kg}$ per day and tapered down to 0 . Seventeen $(85 \%)$ of patients achieved relapse-free survival patterns in the tocilizumab group and two (20\%) in the placebo group (risk difference: 65\%, 95\% CI: $36-94 ; p=0.0010)$. The mean survival time difference to stop glucocorticoids was 12 weeks in favor of tocilizumab (95\% CI: 7-17; $p<$ 0.0001 ), leading to a cumulative prednisolone dose of $43 \mathrm{mg} / \mathrm{kg}$ in the tocilizumab group versus $110 \mathrm{mg} / \mathrm{kg}$ in the placebo group ( $p=$ $0.0005)$ after 52 weeks. Serious adverse events affected seven patients (35\%) in the tocilizumab group and five (50\%) in the placebo group. These results show the marked efficacy of tocilizumab for the induction and maintenance of remission in patients with GCA.

PMR is a chronic inflammatory disease affecting the elderly. It is characterized by aching and morning stiffness in the shoulders, neck, and pelvic girdles. Onset of this disorder often occurs in association with GCA. IL-6 has been recognized as the most sensitive marker of disease activity and course. In a prospective openlabel study (NCT01713842), 20 glucocorticoidfree patients with symptom onset within the previous 12 months and a PMR activity score (PMR-AS) of $>10$ received three infusions of $8 \mathrm{mg} / \mathrm{kg}$ tocilizumab every 4 weeks, followed by prednisolone from weeks 12 to $24(0.15 \mathrm{mg} / \mathrm{kg}$ if PMR-AS $<10$ and $0.30 \mathrm{mg} / \mathrm{kg}$ otherwise) (Devauchelle-Pensec et al. 2016). Baseline median PMR-AS was 36.6, but by week 12 the score had become $<10$ in all patients, so that all patients subsequently received the low dose of prednisolone. Median PMR-AS was 4.5 by week 12 and 0.95 by week 24 . In another open-label clinical trial (NCT01396317), 10 patients with newly diagnosed PMR and prior treatment with less than 1 month of glucocorticoids were treated with $8 \mathrm{mg} / \mathrm{kg}$ tocilizumab every 4 weeks intravenously plus a standardized rapid steroid taper (Lally et al. 2016). The primary end point was the percentage of subjects in relapse-free remission without glucocorticoids at 6 months. 
One patient withdrew after 2 months, but the other nine patients attained the primary end point and remained in remission without relapse throughout the entire 15-month study. These findings indicate that tocilizumab is effective for recent-onset PMR.

\section{APPLICATION OF IL-6 BLOCKADE IMMUNOTHERAPY FOR ACUTE INFLAMMATORY DISEASES}

In addition to these potential indications for treatment with tocilizumab of a variety of chronic diseases, it could potentially serve as rescue therapy for acute life-threatening conditions such as cytokine storm and myocardial infarction.

\section{Cytokine Storm}

A cytokine storm is a potentially fatal immune reaction with highly elevated levels of various cytokines caused by extremely activated immune cells such as T cells, macrophages, and/ or histiocytes in response to infections, tissue injuries, and autoimmune reaction.

Cytokine release syndrome (CRS) entails severe or fatal acute complications and is induced by nonphysiologic T-cell activation after T-cellengaging therapies using chimeric antigen receptor-modified T cells (CAR-T) or a CD19/ CD3-bi-specific antibody (blinatumomab) (Maude et al. 2014a). IL-6, IL-8, IL-10, and MCP-1, as well as the effector cytokine, IFN- $\gamma$, have been shown to be markedly elevated in patients with CRS. However, one administration of tocilizumab to the first patient with CRS as a complication of CAR-T therapy dramatically and unexpectedly resolved her serious condition (Grupp et al. 2013). Moreover, CRS induced by blinatumomab treatment of another patient, who presented with hemophagocytic lymphohistiocytosis with multisystem organ failure, was rapidly alleviated after one injection of tocilizumab (Teachey et al. 2013). Before tocilizumab therapy, this patient's serum levels of IFN- $\gamma$, IL-6, IL-8, IL-10, and MCP-1 were highly elevated, but tocilizumab injection resulted in a reduction in all elevated cytokine levels. In a subsequent study, 30 patients with acute lymphoblastic leukemia treated with CAR-T therapy had mild-to-severe CRS, with severe CRS in $27 \%$ of the patients, who required intensive care because of respiratory failure, coagulopathy, and hypotension (Maude et al. 2014b). In the patients with severe CRS, serum IL-6 levels were $>1000 \mathrm{pg} / \mathrm{mL}$, but again tocilizumab could produce a rapid and profound improvement in their severe clinical manifestations in only 1 to 3 days. These findings point to the possibility that IL-6 blockade may constitute a novel therapeutic strategy for emergent fatal complications mediated by "cytokine storm" (Tanaka et al. 2016).

A cytokine storm is induced by numerous conditions, which include, in addition to CRS, SIRS, macrophage-activation syndrome, and hemophagocytic lymphohistiocytosis. SIRS is composed of a variety of diseases: infection-induced SIRS (sepsis) and noninfectious SIRS such as trauma, burns, acute pancreatitis, heat stroke, crush syndrome, blast injury, graft-versus-host disease, ischemia, and hemorrhage. Surgery-related complications, adrenal insufficiency, pulmonary embolism, and aortic aneurysm can also lead to SIRS, and a biological drug against CD28 was also reported to induce SIRS (Suntharalingam et al. 2006). Although the mortality rate for SIRS is very high, an effective immunomodulation therapy has not yet been established. In fact, more than 100 clinical trials of biologics, including TNF and IL-1 inhibitors and other agents for the treatment of sepsis, have been conducted, yet no effective drug has been found.

IL-6 is an attractive target molecule for SIRS. As mentioned previously, the complex IL-6/sIL-6R is implicated in the induction of thrombosis, vascular leakage, and myocardial dysfunction, leading to multiple organ dysfunction and DIC (Kruttgen and Rose-John 2011). Moreover, numerous studies have shown IL-6 to be an excellent biomarker of severity and prognostic indicator of outcome for patients with SIRS. In patients with severe multiple organ dysfunction, serum levels of IL-6 can increase to $>1000 \mathrm{pg} / \mathrm{mL}$. Initially, CRS-related cytokines (IL-6, IL-8, IL-10, IFN- $\gamma$, and MCP-1) 
T. Tanaka et al.

as well as other cytokines, including TNF- $\alpha$ and IL-1, are highly expressed in patients with SIRS and sepsis in particular. However, the serum levels of TNF- $\alpha$ and IL-1 return to normal levels within the first few hours and this is one reason why the clinical trials of both TNF and IL-1 inhibitors failed to show effectiveness for sepsis. However, levels of circulating IL-6 as well as of IL-8, IL-10, and MCP-1 persist much longer in patients with sepsis and other SIRS (Kang et al., in prep.). These findings indicate that IL-6 blockade features a broader therapeutic window than other procedures and thus may constitute a novel therapeutic strategy for SIRS. Because the $K_{\mathrm{d}}$ of IL- 6 binding to sIL- $6 \mathrm{R}$ is $\sim 1 \mathrm{~nm}$ and the resultant complex binds to gp130 with a $K_{\mathrm{d}}$ of 10 pM, such highly elevated IL-6 can activate various cells, especially VE cells, through the sIL-6R-mediated trans-signaling mechanism, resulting in the further secretion of IL-6, IL-8, and MCP-1. Thus, as seen in CRS complicated with T-cell engaging therapy, tocilizumab therapy may possibly lead to suppression of all these cytokines in SIRS, irrespective of underlying diseases, by suppressing activation of VE cells. If this is the case, IL- 6 blockade will become a novel therapeutic approach for a wide variety of acute severe systemic inflammatory diseases presenting with "cytokine storm," although additional clinical studies are required to verify this possibility.

\section{Myocardial Infarction}

IL-6 contributes to atherosclerotic plaque development and is involved in ischemia-reperfusion myocardial injury. In a two-center, doubleblind, placebo-controlled trial, 117 patients with non-ST-elevation myocardial infarction were randomized at a median of 2 days after symptom onset to receive $240 \mathrm{mg}$ of tocilizumab or placebo intravenously before coronary angiography (NCT01491074) (Kleveland et al. 2016). The area under the curve (AUC) for CRP and troponin $\mathrm{T}$ (a marker of myocardial damage) at seven time points between days 1 and 3 was measured. Median AUC for CRP was 2.1 times higher for the placebo group than for the tocilizumab group ( 4.2 vs. $2.0 \mathrm{mg} / \mathrm{L} / \mathrm{h} ; p$
$<0.001$ ), whereas median AUC for troponin T was also higher for the placebo group compared with the tocilizumab group (234 vs. $159 \mathrm{ng} / \mathrm{L} /$ $\mathrm{h} ; p=0.007)$. These findings indicate that tocilizumab can protect against inflammation as well as myocardial damage induced by myocardial infarction, leading to a clinical trial of short-term application of tocilizumab following myocardial infarction (NCT 02419937).

\section{CONCLUDING REMARKS}

In parallel with the discovery of IL- 6 and subsequent elucidation of the IL- 6 signaling system, the pathological involvement of IL- 6 in various diseases was also ascertained. This was followed by the development of the IL-6 inhibitor tocilizumab, which is currently used for the treatment of Castleman disease, RA, and systemic and polyarticular JIA. It is anticipated that, during the next decade, the IL- 6 inhibitor will be widely used for the treatment of various as yet intractable diseases, including cytokine storm, and that its use will overcome the refractoriness of such diseases. To achieve this goal, however, further clinical evaluations will be essential.

Nevertheless, one conundrum remains to be solved, namely, why is IL-6 excessively or persistently expressed in various diseases? The IL-6 synthesis is controlled by transcription and posttranscriptional regulations. As described elsewhere, Arid5a stabilizes IL-6 as well as STAT3 mRNA by competing with degrading functions of Regnase-1 and forms a positive loop between IL-6 and STAT3. Accurate and detailed analyses of such RNA-binding proteins and of other regulators, which affect IL-6 synthesis, will certainly contribute to solving this mystery, while clarification of the mecha$\operatorname{nism}(\mathrm{s})$ involved will facilitate the identification of more specific target molecules and investigation into the pathogenesis of specific diseases.

\section{ACKNOWLEDGMENTS}

T.K. holds a patent for tocilizumab and has received royalties for Actemra. T.T. has received a grant and payment for lectures, including services for speakers' bureaus from Chugai Phar- 
maceutical Co., Ltd. The Department of Clinical Application of Biologics of Osaka University Graduate School of Medicine is an endowment department, supported with an unrestricted grant from Chugai Pharmaceutical Co., Ltd. M.N. has received payment for lectures, including services for speakers' bureaus from Chugai Pharmaceutical Co., Ltd.

\section{REFERENCES}

Akira S, Kishimoto T. 1992. IL-6 and NF-IL6 in acutephase response and viral infection. Immunol Rev 127: 25-50.

Akira S, Taga T, Kishimoto T. 1993. Interleukin-6 in biology and medicine. Adv Immunol 54: 1-78.

Anderson P. 2008. Post-transcriptional control of cytokine production. Nature Immunol 9: 353-359.

Araki M, Matsuoka T, Miyamoto K, Kusunoki S, Okamoto T, Murata M, Miyake S, Aranami T, Yamamura T. 2014. Efficacy of the anti-IL-6 receptor antibody tocilizumab in neuromyelitis optica: A pilot study. Neurology 82: $1302-$ 1306.

Ballard DW, Bohnlein E, Lowenthal JW, Wano Y, Franza BR, Greene WC. 1988. HTLV-I tax induces cellular proteins that activate the $\kappa \mathrm{B}$ element in the IL-2 receptor $\alpha$ gene. Science 241: 1652-1655.

Boulanger MJ, Chow DC, Brevnova EE, Garcia KC. 2003. Hexameric structure and assembly of the interleukin-6/ IL-6 $\alpha$-receptor/gp130 complex. Science 300: 2101-2104.

Chen CY, Shyu AB. 1995. AU-rich elements: Characterization and importance in mRNA degradation. Trends Biochem Sci 20: 465-470.

Chihara N, Aranami T, Sato W, Miyazaki Y, Miyake S, Okamoto T, Ogawa M, Toda T, Yamamura T. 2011. Interleukin 6 signaling promotes anti-aquaporin 4 autoantibody production from plasmablasts in neuromyelitis optica. Proc Natl Acad Sci 108: 3701-3706.

Choy EH, Isenberg DA, Garrood T, Farrow S, Ioannou Y, Bird H, Cheung N, Williams B, Hazleman B, Price R, et al. 2002. Therapeutic benefit of blocking interleukin-6 activity with an anti-interleukin-6 receptor monoclonal antibody in rheumatoid arthritis: A randomized, double-blind, placebo-controlled, dose-escalation trial. Arthritis Rheum 46: 3143-3150.

Cohen T, Nahari D, Cerem LW, Neufeld G, Levi BZ. 1996. Interleukin 6 induces the expression of vascular endothelial growth factor. J Biol Chem 271: 736-741.

De Benedetti F, Brunner HI, Ruperto N, Kenwright A, Wright S, Calvo I, Cuttica R, Ravelli A, Schneider R, Woo P, et al. 2012. Randomized trial of tocilizumab in systemic juvenile idiopathic arthritis. N Engl J Med 367: 2385-2395.

Deisseroth A, Ko CW, Nie L, Zirkelbach JF, Zhao L, Bullock J, Mehrotra N, Del Valle P, Saber H, Sheth C, et al. 2015 FDA approval: Siltuximab for the treatment of patients with multicentric Castleman diseases. Clin Cancer Res 21: 950-954.
Desai TR, Leeper NJ, Hynes KL, Gewertz BL. 2002. Interleukin-6 causes endothelial barrier dysfunction via the protein kinase C pathway. J Surg Res 104: 118-123.

Devauchelle-Pensec V, Berthelot JM, Cornec D, Renaudineau Y, Marhadour T, Jousse-Joulin S, Querellou S, Garrigues F, De Bandt M, Gouillou M, et al. 2016. Efficacy of first-line tocilizumab therapy in early polymyalgia rheumatica: A prospective longitudinal study. Ann Rheum Dis 75: $1506-1510$.

Esser S, Lampugnani MG, Corada M, Dejana E, Risau W. 1998. Vascular endothelial growth factor induces VEcadherin tyrosine phosphorylation in endothelial cells. J Cell Sci 111: 1853-1865.

Finkel MS, Oddis CV, Jacob TD, Watkins SC, Hattler BG, Simmons RL. 1992. Negative inotropic effects of cytokines on heart mediated by nitric oxide. Science 257: 387-389.

Gabay C, Emery P, van Vollenhoven R, Dikranian A, Alten R, Pavelka K, Klearman M, Musselman D, Agrawal S, Green J, et al. 2013. Tocilizumab monotherapy versus adalimumab monotherapy for treatment of rheumatoid arthritis (ADACTA): A randomised, double-blind, controlled phase 4 trial. Lancet 381: $1541-1550$.

Gillmore JD, Lovat LB, Persey MR, Pepys MB, Hawkins PN. 2001. Amyloid load and clinical outcome in AA amyloidosis in relation to circulating concentration of serum amyloid A protein. Lancet 358: 24-29.

Grupp SA, Kalos M, Barrett D, Aplenc R, Porter DL, Rheingold SR, Teachey DT, Chew A, Hauck B, Wright JF, et al. 2013. Chimeric antigen receptor-modified T cells for acute lymphoid leukemia. N Engl J Med 368: 1509-1518.

Hashimoto-Kataoka T, Hosen N, Sonobe T, Arita Y, Yasui T, Masaki T, Minami M, Inagaki T, Miyagawa S, Sawa Y, et al. 2015. Interleukin-6/interleukin-21 signaling axis is critical in the pathogenesis of pulmonary arterial hypertension. Proc Natl Acad Sci 112: 2677-2686.

Hashizume M, Hayakawa N, Mihara M. 2008. IL-6 transsignalling directly induces RANKL on fibroblast-like synovial cells and is involved in RANKL induction by TNF- $\alpha$ and IL-17. Rheumatology (Oxford) 47: 16351640.

He M, Xu Z, Ding T, Kuang DM, Zheng L. 2009. microRNA155 regulates inflammatory cytokine production in tumor-associated macrophages via targeting C/EBP 3 . Cell Mol Immunol 6: 343-352.

Heinrich PC, Castell JV, Andus T. 1990. Interleukin-6 and the acute phase response. Biochem J 265: 621-636.

Hibi M, Murakami M, Saito M, Hirano T, Taga T, Kishimoto T. 1990. Molecular cloning and expression of an IL-6 signal transducer, gp130. Cell 63: 1149-1157.

Hirano T, Yasukawa K, Harada H, Taga T, Watanabe Y, Matsuda T, Kashiwamura S, Nakajima K, Koyama K, Iwamatsu A, et al. 1986. Complementary DNA for a novel human interleukin (BSF-2) that induces B lymphocytes to produce immunoglobulin. Nature 324: 73-76.

Hirano T, Taga T, Yasukawa K, Nakajima K, Nakano N, Takatsuki F, Shimizu M, Murashima A, Tsunasawa S, Sakiyama F, et al. 1987. Human B-cell differentiation factor defined by an anti-peptide antibody and its possible role in autoantibody production. Proc Natl Acad Sci 84: 228 231. 
T. Tanaka et al.

Hirano T, Matsuda T, Turner M, Miyasaka N, Buchan G Tang B, Sato K, Shimizu M, Maini R, Feldmann M, et al. 1988. Excessive production of interleukin 6/B cell stimulatory factor-2 in rheumatoid arthritis. Eur J Immunol 18: $1797-1801$.

Igawa T, Ishii S, Tachibana T, Maeda A, Higuchi Y, Shimaoka S, Moriyama C, Watanabe T, Takubo R, Doi Y, et al. 2010. Antibody recycling by engineered $\mathrm{pH}$-dependent antigen binding improves the duration of antigen neutralization Nat Biotechnol 28: 1203-1207.

Ishibashi T, Kimura H, Shikama Y, Uchida T, Kariyone S, Hirano T, Kishimoto T, Takatsuki F, Akiyama Y. 1989. Interleukin-6 is a potent thrombopoietic factor in vivo in mice. Blood 74: 1241-1244.

Kawano M, Hirano T, Matsuda T, Taga T, Horii Y, Iwato K, Asaoku H, Tang B, Tanabe O, Tanaka H, et al. 1988 . Autocrine generation and requirement of BSF-2/IL-6 for human multiple myelomas. Nature 332: 83-85.

Khanna D, Denton CP, Jahreis A, van Laar JM, Frech TM, Anderson ME, Baron M, Chung L, Fierlbeck G, Lakshminarayanan S, et al. 2016. Safety and efficacy of subcutaneous tocilizumab in adults with systemic sclerosis (faSScinate): A phase 2, randomised controlled trial. Lancet 387: 2630-2640.

Kimura A, Kishimoto T. 2010. IL-6: Regulator of Treg/Th17 balance. Eur J Immunol 40: 1830-1835.

Kishimoto T. 1985. Factors affecting B-cell growth and differentiation. Annu Rev Immunol 3: 133-157.

Kishimoto T. 1989. The biology of interleukin-6. Blood 74: $1-10$.

Kishimoto T. 2005. Interleukin-6: From basic science to medicine—40 years in immunology. Annu Rev Immunol 23: $1-21$.

Kishimoto T, Akira S, Taga T. 1992. Interleukin-6 and its receptor: A paradigm for cytokines. Science 258: $593-$ 597.

Kishimoto T, Taga T, Akira S. 1994. Cytokine signal transduction. Cell 76: 253-262.

Kleveland O, Kunszt G, Bratlie M, Ueland T, Brock K, Holte E, Michelsen AE, Bendz B, Amundsen BH, Espevik T, et al. 2016. Effect of a single dose of the interleukin-6 receptor antagonist tocilizumab on inflammation and troponin $\mathrm{T}$ release in patients with non-ST-elevation myocardial infarction: A double-blind, randomized, placebo-controlled phase 2 trial. Eur Heart J 37: $2406-$ 2413.

Kotake S, Sato K, Kim KJ, Takahashi N, Udagawa N, Nakamura I, Yamaguchi A, Kishimoto T, Suda T, Kashiwazaki S. 1996. Interleukin-6 and soluble interleukin-6 receptors in the synovial fluids from rheumatoid arthritis patients are responsible for osteoclast-like cell formation. J Bone Miner Res 11: 88-95.

Kruttgen A, Rose-John S. 2011. Interleukin-6 in sepsis and capillary leakage syndrome. J Interferon Cytokine Res 32: $60-65$.

Lally L, Forbess L, Hatzis C, Spiera R. 2016. A prospective open label phase IIa trial of tocilizumab in the treatment of polymyalgia rheumatica. Arthritis Rheumatol 68: 2550-2554.

Laudes IJ, Chu JC, Huber-Lang M, Guo RF, Riedemann NC, Sarma JV, Mahdi F, Murphy HS, Speyer C, Lu KT, et al.
2002. Expression and function of C5a receptor in mouse microvascular endothelial cells. J Immunol 169: 5962 5970.

Libermann TA, Baltimore D. 1990. Activation of interleukin-6 gene expression through the NF-кB transcription factor. Mol Cell Biol 10: 2327-2334.

Ma CS, Deenick EK, Batten M, Tangye SG. 2012. The origins, function, and regulation of T follicular helper cells. J Exp Med 209: 1241-1253.

Masuda K, Kishimoto T. 2016. CD5: A new partner for IL-6. Immunity 44: 720-722.

Masuda K, Ripley B, Nishimura R, Mino T, Takeuchi O, Shioi G, Kiyonari H, Kishimoto T. 2013. Arid5a controls IL-6 mRNA stability, which contributes to elevation of IL-6 level in vivo. Proc Natl Acad Sci 110: 9409-9414.

Masuda K, Ripley B, Nyati KK, Dubey PK, Zaman MM, Hanieh H, Higa M, Yamashita K, Standley DM, Mashima T, et al. 2016. Arid5a regulates naïve $\mathrm{CD}^{+} \mathrm{T}$ cell fate through selective stabilization of Stat3 mRNA. J Exp Med 213: 605-619.

Matsushita K, Takeuchi O, Standley DM, Kumagai Y, Kawagoe T, Miyake T, Satoh T, Kato H, Tsujimura T, Nakamura $\mathrm{H}$, et al. 2009. Zc3h12a is an RNase essential for controlling immune responses by regulating mRNA decay. $\mathrm{Na}$ ture 458: 1185-1190.

Maude SL, Barrett D, Teachey DT, Grupp SA. 2014a. Managing cytokine release syndrome associated with novel T cell-engaging therapies. Cancer J 20: 119-122.

Maude SL, Frey N, Shaw PA, Aplenc R, Barrett DM, Bunin NJ, Chew A, Gonzalez VE, Zheng Z, Lacey SF, et al. 2014b. Chimeric antigen receptor $\mathrm{T}$ cells for sustained remissions in leukemia. N Engl J Med 371: 1507-1517.

Mauer J, Chaurasia B, Goldau J, Vogt MC, Ruud J, Nguyen KD, Theurich S, Hausen AC, Schmitz J, Bronneke HS, et al. 2014. Signaling by IL-6 promotes alternative activation of macrophages to limit endotoxemia and obesityassociated resistance to insulin. Nat Immunol 15: $423-$ 430.

Mino T, Murakawa Y, Fukao A, Vandenbon A, Wessels HH, Ori D, Uehata T, Tartey S, Akira S, Suzuki Y, et al. 2015. Regnase-1 and roquin regulate a common element in inflammatory mRNAs by spatiotemporally distinct mechanisms. Cell 161: 1058-1073.

Murakami M, Hibi M, Nakagawa N, Nakagawa T, Yasukawa K, Yamanishi K, Taga T, Kishimoto T. 1993. IL-6-induced homodimerization of gp130 and associated activation of a tyrosine kinase. Science 260: 1808-1810.

Naka T, Narazaki M, Hirata M, Matsumoto T, Minamoto S, Aono A, Nishimoto N, Kajita T, Taga T, Yoshizaki K, et al. 1997. Structure and function of a new STAT-induced STAT inhibitor. Nature 387: 924-929.

Narazaki M, Yasukawa K, Saito T, Ohsugi Y, Fukui H, Koishihara Y, Yancopoulos GD, Taga T, Kishimoto T. 1993. Soluble forms of the interleukin-6 signal-transducing receptor component gp130 in human serum possessing a potential to inhibit signals through membrane-anchored gp130. Blood 82: 1120-1126.

Nemeth E, Rivera S, Gabayan V, Keller C, Taudorf S, Pedersen BK, Ganz T. 2004. IL-6 mediates hypoferremia of inflammation by inducing the synthesis of the iron regulatory hormone hepcidin. J Clin Invest 113: 1271-1276. 
Neumann FJ, Ott I, Marx N, Luther T, Kenngott S, Gawaz M, Kotzsch M, Schomig A. 1997. Effect of human recombinant interleukin- 6 and interleukin-8 on monocyte procoagulant activity. Arterioscler Thromb Vasc Biol 17: 3399-3405.

Nishimoto N, Sasai M, Shima Y, Nakagawa M, Matsumoto T, Shirai T, Kishimoto T, Yoshizaki K. 2000. Improvement in Castleman's disease by humanized anti-interleukin-6 receptor antibody therapy. Blood 95: 56-61.

Nishimoto N, Yoshizaki K, Miyasaka N, Yamamoto K, Kawai S, Takeuchi T, Hashimoto J, Azuma J, Kishimoto T. 2004. Treatment of rheumatoid arthritis with humanized anti-interleukin-6 receptor antibody: A multicenter, double-blind, placebo-controlled trial. Arthritis Rheum 50: $1761-1769$.

Nishimoto N, Kanakura Y, Aozasa K, Johkoh T, Nakamura M, Nakano S, Nakano N, Ikeda Y, Sasaki T, Nishioka K, et al. 2005. Humanized anti-interleukin-6 receptor antibody treatment of multicentric Castleman disease. Blood 106: $2627-2632$.

Pathan N, Hemingway CA, Alizadeh AA, Stephens AC, Boldrick JC, Oragui EE, McCabe C, Welch SB, Whitney A, O'Gara P, et al. 2004. Role of interleukin 6 in myocardial dysfunction of meningococcal septic shock. Lancet 363: 203-209.

Riedemann NC, Neff TA, Guo RF, Bernacki KD, Laudes IJ, Sarma JV, Lambris JD, Ward PA. 2003. Protective effects of IL-6 blockade in sepsis are linked to reduced C5a receptor expression. J Immunol 170: 503-507.

Romano M, Sironi M, Toniatti C, Polentarutti N, Fruscella P, Ghezzi P, Faggioni R, Luini W, van Hinsbergh V, Sozzani S, et al. 1997. Role of IL-6 and its soluble receptor in induction of chemokines and leukocyte recruitment. Immunity 6: 315-325.

Sato K, Tsuchiya M, Saldanha J, Koishihara Y, Ohsugi Y, Kishimoto T, Bendig MM. 1993. Reshaping a human antibody to inhibit the interleukin 6-dependent tumor cell growth. Cancer Res 53: 851-856.

Scala G, Ruocco MR, Ambrosino C, Mallardo M, Giordano V, Baldassarre F, Dragonetti E, Quinto I, Venuta S. 1994. The expression of the interleukin 6 gene is induced by the human immunodeficiency virus 1 TAT protein. $J$ Exp Med 179: 961-971.

Schmitz J, Weissenbach M, Haan S, Heinrich PC, Schaper F. 2000. SOCS3 exerts its inhibitory function on interleukin-6 signal transduction through the SHP2 recruitment sites of gp130. J Biol Chem 275: 12848-12856.

Shima Y, Kuwahara Y, Murota H, Kitaba S, Kawai M, Hirano T, Arimitsu J, Narazaki M, Hagihara K, Ogata A, et al. 2010. The skin of patients with systemic sclerosis softened during the treatment with anti-IL-6 receptor antibody tocilizumab. Rheumatology (Oxford) 49: 2408-2412.

Singh JA, Saag KG, Bridges SL Jr, Akl EA, Bannuru RR, Sullivan MC, Vaysbrot E, McNaughton C, Osani M, Shmerling RH, et al. 2016. 2015 American College of Rheumatology guideline for the treatment of rheumatoid arthritis. Arthritis Rheumatol 68: 1-26.

Smolen JS, Landewe R, Breedveld FC, Buch M, Burmester G, Dougados M, Emery P, Gaujoux-Viala C, Gosses L, Nam $\mathrm{J}$, et al. 2014. EULAR recommendations for the manage- ment of rheumatoid arthritis with synthetic and biological disease-modifying antirheumatic drugs. 2013 update. Ann Rheum Dis 73: 492-509.

Suntharalingam G, Perry MR, Ward S, Brett SJ, CastelloCortes A, Brunner MD, Panoskaltsis N. 2006. Cytokine storm in a phase 1 trial of the anti-CD28 monoclonal antibody TGN1412. N Engl J Med 355: 1018-1028.

Taga T, Kishimoto T. 1997. Gp130 and the interleukin-6 family of cytokines. Annu Rev Immunol 15: 797-819.

Tanaka T, Kishimoto T. 2014. The biology and medical implications of interleukin-6. Cancer Immunol Res 2: 288294.

Tanaka T, Narazaki M, Kishimoto T. 2012. Therapeutic targeting of the interleukin-6 receptor. Annu Rev Pharmacol Toxicol 52: 199-219.

Tanaka T, Ogata A, Narazaki M. 2013. Tocilizumab: An updated review of its use in the treatment of rheumatoid arthritis and its application for other immune-mediated diseases. Clin Med Insights Ther 5: 33-52.

Tanaka T, Narazaki M, Kishimoto T. 2014a. IL-6 in inflammation, immunity, and disease. Cold Spring Harb Perspect Biol 6: a016295.

Tanaka T, Narazaki M, Ogata A, Kishimoto T. 2014b. A new era for the treatment of inflammatory autoimmune diseases by interleukin-6 blockade strategy. Semin Immunol 26: $88-96$

Tanaka T, Narazaki M, Kishimoto T. 2016. Immunotherapeutic implications of IL-6 blockade for cytokine storm. Immunotherapy 8: 959-970.

Teachey DT, Rheingold SR, Maude SL, Zugmaier G, Barrett DM, Seif AE, Nichols KE, Suppa EK, Kalos M, Berg RA, et al. 2013. Cytokine release syndrome after blinatumomab treatment related to abnormal macrophage activation and ameliorated with cytokine-directed therapy. Blood 121: $5154-5157$.

Villiger PM, Adler S, Kuchen S, Wermelinger F, Dan D, Fiege V, Butikofer L, Seitz M, Reichenbach S. 2016. Tocilizumab for induction and maintenance of remission in giant cell arteritis: A phase 2, randomised, double-blind, placebocontrolled trial. Lancet 387: 1921-1927.

Yamasaki K, Taga T, Hirata Y, Yawata H, Kawanishi Y, Seed B, Taniguchi T, Hirano T, Kishimoto T. 1988. Cloning and expression of the human interleukin-6 (BSF-2/IFN 32 ) receptor. Science 241: 825-828.

Yokota S, Imagawa T, Mori M, Miyamae T, Aihara Y, Takei S, Iwata N, Umebayashi H, Murata T, Miyoshi M, et al. 2008. Efficacy and safety of tocilizumab in patients with systemic-onset juvenile idiopathic arthritis: A randomized, double-blind, placebo-controlled, withdrawal phase III trial. Lancet 371: 998-1006.

Yoshizaki K, Matsuda T, Nishimoto N, Kuritani T, Taeho L, Aozasa K, Nakahata T, Kawai H, Tagoh H, Komori T, et al 1989. Pathogenic significance of interleukin-6 (IL-6/ BSF-2) in Castleman's disease. Blood 74: 1360-1367.

Zhang C, Xin H, Zhang W, Yazaki PJ, Zhang Z, Le K, Li W, Lee H, Kwak L, Forman S, et al. 2016. CD5 binds to interleukin-6 and induces a feed-forward loop with the transcription factor STAT3 in B cells to promote cancer. Immunity 44: 913-923. 


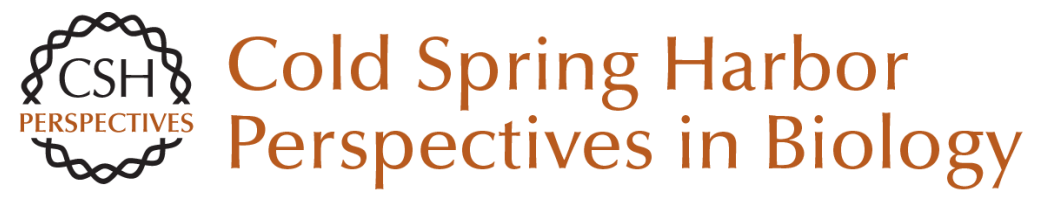

\section{Interleukin (IL-6) Immunotherapy}

Toshio Tanaka, Masashi Narazaki and Tadamitsu Kishimoto

Cold Spring Harb Perspect Biol 2018; doi: 10.1101/cshperspect.a028456 originally published online August 4, 2017

\section{Subject Collection Cytokines}

Interleukin (IL)-33 and the IL-1 Family of Cytokines --Regulators of Inflammation and Tissue Homeostasis

Ajithkumar Vasanthakumar and Axel Kallies

Targeting IL-10 Family Cytokines for the Treatment of Human Diseases Xiaoting Wang, Kit Wong, Wenjun Ouyang, et al.

Cytokine-Mediated Regulation of CD8 T-Cell Responses During Acute and Chronic Viral Infection

Masao Hashimoto, Se Jin Im, Koichi Araki, et al.

Cytokines in Cancer Immunotherapy

Thomas A. Waldmann

The Tumor Necrosis Factor Family: Family Conventions and Private Idiosyncrasies David Wallach

The Interferon (IFN) Class of Cytokines and the IFN Regulatory Factor (IRF) Transcription Factor Family

Hideo Negishi, Tadatsugu Taniguchi and Hideyuki Yanai
Interferon $\gamma$ and Its Important Roles in Promoting and Inhibiting Spontaneous and Therapeutic Cancer Immunity

Elise Alspach, Danielle M. Lussier and Robert D. Schreiber

Inflammasome-Dependent Cytokines at the Crossroads of Health and Autoinflammatory Disease

Hanne Van Gorp, Nina Van Opdenbosch and Mohamed Lamkanfi

Innate Lymphoid Cells (ILCs): Cytokine Hubs Regulating Immunity and Tissue Homeostasis Maho Nagasawa, Hergen Spits and Xavier Romero Ros

T Helper Cell Differentiation, Heterogeneity, and

Plasticity Jinfang Zhu

Development, Diversity, and Function of Dendritic Cells in Mouse and Human

David A. Anderson III, Kenneth M. Murphy and Carlos G. Briseño

Cytokines and Long Noncoding RNAs Susan Carpenter and Katherine A. Fitzgerald

For additional articles in this collection, see http://cshperspectives.cshlp.org/cgi/collection/

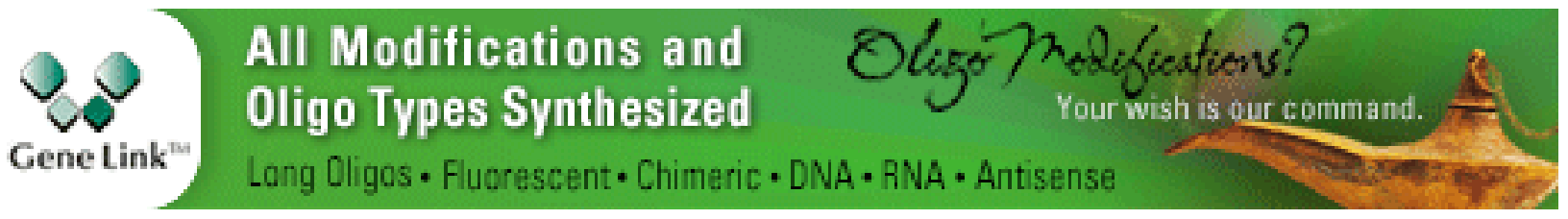

Copyright @ 2018 Cold Spring Harbor Laboratory Press; all rights reserved 
Role of the $\beta$ Common $(\beta \mathrm{c})$ Family of Cytokines in Health and Disease

Timothy R. Hercus, Winnie L. T. Kan, Sophie E. Broughton, et al.

Interleukin (IL)-12 and IL-23 and Their Conflicting Roles in Cancer Juming Yan, Mark J. Smyth and Michele W.L. Teng
Negative Regulation of Cytokine Signaling in Immunity

Akihiko Yoshimura, Minako Ito, Shunsuke Chikuma, et al.

Cancer Inflammation and Cytokines

Maria Rosaria Galdiero, Gianni Marone and Alberto Mantovani

For additional articles in this collection, see http://cshperspectives.cshlp.org/cgi/collection/

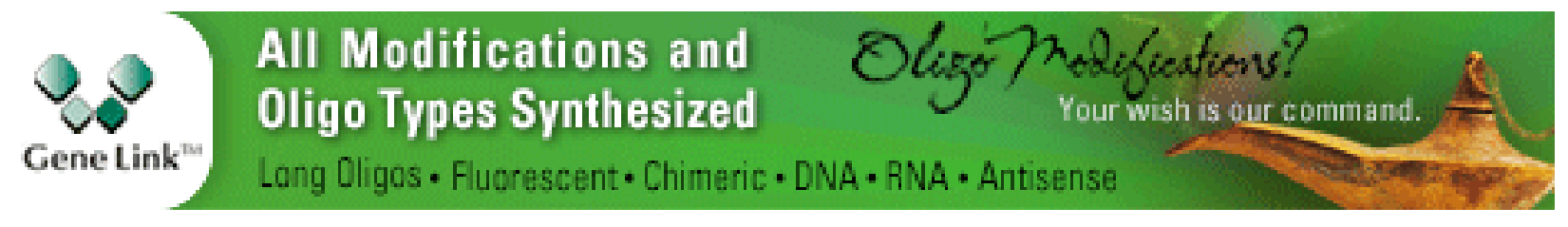

Copyright @ 2018 Cold Spring Harbor Laboratory Press; all rights reserved 